Original Article

\title{
An Overview of Spiritually Oriented Cognitive Behavioral Therapy
}

\author{
Ayfer Summermatter ${ }^{1}$ \\ Marmara University
}

\author{
Çınar Kaya ${ }^{2}$ \\ Marmara University
}

\begin{abstract}
While spirituality/religion has a healing effect for some individuals, for others it may have the opposite effect of enhancing psychological symptoms. For this reason, efforts are being made to address spirituality as a therapeutic or accelerating factor and reduce the potential negative effects of spirituality in the therapy process. The effectiveness of these applications is investigated in various studies. A comprehensive literature is being formed out of the studies conducted worldwide. Newly started studies in Turkey and similar countries are promising, but there are few coherent examples of how to address spirituality in therapy. In this article, the techniques and applications used in spiritually oriented cognitive behavioral therapy have been compiled and therapeutic applications are proposed. Ethical practices and applications specific to Muslim clients are also discussed.
\end{abstract}

\section{Keywords \\ Spirituality $\bullet$ Cognitive behavioral therapy $\bullet$ Spiritually oriented psychotherapy $\bullet$ Religiously oriented} psychotherapy• CBT

\section{Manevi Yönelimli Bilişsel Davranışçı Terapiye Genel Bir Bakış}

Öz

Maneviyat/din, bazı bireyler için iyileștirici etki gösterirken, bazı bireyler içinse tam tersi olarak psikolojik semptomları arttırıcı işlev de görebilmektedir. Bu nedenle maneviyatın terapi sürecinde iyileştirici veya iyileşmeyi hızlandııııı bir etken olarak kullanılmasına ve olası olumsuz etkilerini azaltmaya yönelik çalışmalar yapılmaktadır. Bu çalışmaların etkililiği araştırmalar ile incelenmektedir. Özellikle yurtdışı çalışmalarında artan uygulamalar geniş kapsamlı bir literatürün oluşumuna doğru yol almaktadır. Türkiye ve benzer ülkelerde ise yeni yeni başlayan çalışmalar umut vericidir; fakat maneviyatın terapide nasıl kullanılacağına dair uygulama örnekleri azdır. Bu makale kapsamında bilişsel davranışçı terapi özelinde uluslararası literatürde yer alan manevi yönelimli terapi uygulamaları incelenmiş ve bu araştırmalarda kullanılan teknikler derlenerek terapötik uygulamalar tanıtılmaya çalışılmıștır. Ayrıca etik uygulamalar ve Müslüman danışanlarla yapilan çalışmalara da yer verilmiştir.

\section{Anahtar Kelimeler}

Spirituality Maneviyat • Bilişsel davranışçı terapi • Dini yönelimli terapi $\bullet$ Manevi yönelimli terapi • BDT

1 Correspondence to: Ayfer Summermatter (PhD) Student, Department of Educational Sciences, Marmara University, Goztepe Campus, Kadikoy 34722, Istanbul Turkey. Email: ayfer@asummermatter.com

2 Department of Educational Sciences, Marmara University, Kadiköy 34722, Istanbul Turkey. Email: cinar.kaya@marmara.edu.tr 
Before proceeding to religiously/spiritually oriented cognitive behavioral therapy practices, it may be useful to examine the concepts of religion and spirituality. Knowing what these concepts mean to people, can provide a basic perspective to the therapist, aiming to address these phenomena in therapy sessions. From an examination of the literature, however, it is not so easy to define the concepts of religion and spirituality though these are part of our everyday life. Hill et al. (2000) describe religion as a belief system characterized by a general agreement on faith and worship in community and the existence of traditional actions. Muslim scholars regard religion as not only encompassing faith but also including moral, legal, and social rules that are to guide the worldly life (Harman, 1994). Another fundamental characteristic of religion is that it creates a social union among those who share the same belief and is born out in people who adopt the same forms of behavior. A religious person is a member of both the religious community and the society in which he lives so that he has to comply with the requirements of faith on the one hand and the rules of the community on the other (Polanski, 2003). The common points of all of these definitions is that the religion contains rules governing human life, organizes social life, and makes individuals into a community based on their beliefs. Do people develop systems of religious belief simply in order to create a community and feel safe? If we answer yes to this question, we may be describing religion only within the framework of norms and regulations. Yet, people refer to various positive feelings when describing their religious beliefs. These feelings, often called spirituality, elevate religion above the systems humans build for living together such as government, law, and economy. Spirituality is a phenomenon unique to human beings. This phenomenon is incorporated within religion for some individuals but not for others, either directly or through their application (Polanski, 2003). In this case, it is useful to look separately at definitions of spirituality. Spirituality is the desire to connect with and be close to the sacred. Spirituality leads to the experience of a natural intimacy containing curiosity and admiration. Although there is no agreed upon definition of spirituality, Worthinton \& Aten (2009) suggests four types of spirituality:

$i$. Religious spirituality is defined as feeling the sanctity and affinity that is defined by a particular religion. In many cases, it is based on the sense of feeling close to God or a higher power.

ii. Humanistic spirituality is characterized by the feeling of commitment to humanity, being close to or caring for a larger group of people. Often it is reflected with love, devotion, and sacrifice.

iii. Nature spirituality is defined as the feeling of being connected with the environment or nature, such as when a person witnesses a beautiful natural scene with awe and wonder.

iv. Cosmos spirituality is characterized by a sense of connectedness with creation, such as when contemplating the boundaries of the cosmos. 
As can be seen from all these definitions, spirituality can be understood as the thoughts, feelings, and behaviors of a person relating to the sacred. The establishment of a relationship with holiness may not always require a formal religion, but many people realize their spirituality through a religion. This condition, called religiosity, is identified with spiritual thoughts, feelings, and behaviors associated with a more formal organization defined as religion. For many, holiness, or the sacred, corresponds to God, which is defined as a great power. But, besides this, people continue to search for holiness within a larger context, with or without awareness, even when they may reject traditional religious identities, and this plays a critical role in the lives of these clients (Pargament, 2007; Pargaments \& Saunders, 2007). There is a wide overlap between the concepts of religion and spirituality that should be remembered even if they are defined separately in order to facilitate the understanding of spirituality and religiosity (D'Souza \& Rodrigo, 2004). Since spirituality can coexist with religion to a large measure, but can exist without religion as well, only the concept of spirituality will be used to cover both concepts instead of using them separately hereinafter.

\section{Reasons for Addressing Spirituality in Cognitive Behavioral Therapy}

Gender, ethnic identity, age, family, friends, and social and cultural context influence the client's perspective on the world. Clients do not enter psychotherapy in isolation; rather, they bring with them more than just their own selves. At this point, it is especially important to emphasize spirituality. Modern life emphasizes spirituality as a subjective, inner, and private experience (Pargament, 2007). Yet, spiritual beliefs shape how individuals perceive events and the world, and thus their behavior. For example, individuals who grow up in cultures where spiritual goals are very strong may focus on whether they are living "the right life" that is nourished from spiritual sources rather than material ideals. Similarly, people may express behaviors unique to their own spiritual milieu, such as suicide as a form of self-sacrifice in India or Japan, which is difficult for an individual living in Western societies to understand (Sue \& Sue, 2008).

New developments in research and psychology have changed our perspective on the human and human experience. One of these changes is the increasing recognition of the positive and negative effects of spirituality on a person's mental health and the testing of its functioning in the therapeutic processes. Religion is beginning to become a key to therapy for some clients rather than an excluded process. In recent years, many books on the use of spirituality in clinical practice and therapy processes have been published. Spiritual practices are integrated into secular approaches, such as the cognitive behavioral approach and the humanistic approach, along with spirituality-oriented approaches, like pastoral counseling, and transpersonal therapy, and the effectiveness of these applications is being tested (Sperry \& Shafranske, 2007). This literature 
reveals that spirituality has an important place in the mental health of a person, and that its use in therapy has positive results. For example, Rosmarin, Auerbach, BigdaPeyton, Björgvinsson, and Levendusky (2011) in their research on a Jewish and Christian sample found out that as the level of trust in God increased, tolerance of anxiety, uncertainty, and ambiguity increased, and vice versa. In addition, researchers have found that in groups with low trust in a deity or God, interventions aimed at raising this trust increase tolerance levels for uncertainty and anxiety. Rosmarin et al. (2011), in another study, found that for almost all of the cases in which spiritual thoughts related to the symptoms of the clients were investigated, spirituality is seen as a protective resource, including as a coping mechanism against negative stress, and as symptoms worsen, behavioral and cognitive distancing from beliefs is also seen. Likewise, several studies have shown that spiritual thoughts and behaviors of clients may have supportive effects for solving their problems though sometimes they may have a worsening effect on existing problems or be the very cause of the problems (Braam, Klinkenberg, Galenkamp, \& Deeg, 2012; Cole \& Pargament, 1999; Pargament, Zinnbauer, Scott, Butter, Zerowin, \& Stanik, 1998; Snodgrass, 2009; Weber \& Cummings, 2003).

Religious thoughts and behaviors have important roles in both relieving psychopathological symptoms and contributing to them in not only Christian or Jewish populations but also in religious Muslims. In some clinical trials on religious Muslim clients, clinical recovery has shown to be accelerated by the addition of religious-oriented psychotherapy techniques to secular treatments (Vasegh, 2009). Azhar, Varma, and Dhorap (1994) and Razali, Aminah, and Khan (2002) have shown that the use of standard cognitive behavioral therapy and spiritual techniques together accelerate the improvement of religious Muslim counselors who have been diagnosed with generalized anxiety disorder. Similarly, Azhar, and Varma (1995) found that clients who suffered losses and received religious-oriented psychotherapy recovered faster than the control group receiving only standard psychotherapy. When all these studies are examined, it is seen that spirituality is related to all aspects and expressions of human behaviors in positive and negative senses and emotions and experiences; further, it has two important effects in terms of clinical applications. First, spirituality is a potential resource for solving people's problems, and second, spirituality can be the source of the problem.

Feeling anger at God, clashing with the congregation or the class of the priesthood, spiritual dilemmas, confusion, and guilt are risk factors that negatively affect physical and mental health (Paloutzian \& Park, 2005; Pargament \& Saunders, 2007). The forgiveness of God, the conviction that everyone can commit sins, that people are not perfect, and that God is always with them, on the other hand, can also give strength and flexibility to the person (Vasegh, 2009). 
A spiritually oriented cognitive behavioral psychotherapy approach assumes that the problems that the client brings in and the solutions to these problems are best understood as embedded in the larger social and cultural context, which includes spiritual beliefs. Pargament (2007) has classified the therapeutic use of spirituality as originating from the client, the therapist or the process. The reasons for using spiritually oriented therapy based on the needs of the client are:

i. If the client has strong spirituality, they cannot leave it out of the session.

ii. Problems related to spirituality can cause psychological problems.

iii. Psychological problems can cause spiritual problems.

iv. Spirituality can be a good resource for solving problems.

v. Spirituality can be a source of resistance to solving the problem.

The greater social, cultural, and/or religious context of the client can bring her to therapy. Reasons for addressing spirituality due to therapist needs are:

i. The therapist cannot exclude his spiritual beliefs from the session.

ii. Involving spirituality in sessions depends on the therapist's professionalism in spiritually oriented therapy.

iii. Spiritually oriented psychotherapy requires the therapist's literacy and competence. This includes spiritual knowledge, openness, tolerance, selfawareness, and authenticity.

The reasons for adopting spiritually oriented psychotherapy to enrich the process are:

i. Psychotherapy has a spiritual dimension.

ii. The spiritual point of view of the therapist and the client affects the therapy.

iii. Psychological and spiritual changes take place together even when sacredness is not a direct focus point.

iv. Techniques are enriched by explicitly focusing any therapeutic method on a dimension of spirituality.

v. Addressing spirituality may enable new perspectives on and solutions to psychological problems.

\section{Basic Concepts of Cognitive Behavioral Therapy and the Use of Spiritual Techniques}

When spiritually oriented cognitive behavioral therapy practices are addressed, it appears that spiritual practices are integrated into the standard therapy approach. 
For this reason, it may be useful to take a look at the general concepts of cognitive behavioral therapy (CBT). CBT is an active, time-limited, current-time-oriented, structured approach that is based on cooperation between the client and the therapist, intervenes in consciousness, and is used in the treatment of psychological disorders such as depression, anxiety, phobias, and pain (Beck, 2005; Beck, Rush, Shaw, \& Emery, 1979; Corey, 2013). In this approach, it is assumed that the basis of the psychological problems is the inaccurate functioning of the cognitive processes. The main focus is on bringing about change in the cognitive processes for attaining the desired changes in behavior and affection, and the client's responsibility to take an active role in the therapy process is emphasized. The therapist uses various cognitive behavioral techniques to generate change, and the client is provided means to test this cognitive change (Corey, 2008). According to this approach, the cognition of the person flowing through the verbal or image forms is the basis of his perceptions and attitudes and is formed by previous experiences. The structures that constitute these basic perceptions are called "schemas" or "core beliefs." For example, a dominant schema such as "I have to do everything perfectly, or I am a failure" can be effective in creating goals and interpreting experiences (Beck et al., 1979, p. 3; DeRubeis, Webb, Tang, \& Beck, 2010). CBT does not claim that the clients create their emotional problems only in their heads. According to CBT, some people may get worse in response to adverse events, for example, in the case of a theft, as thoughts and beliefs may detract from the ability to cope constructively. For example, the individual may not feel safe at home despite numerous security measures (Neenan \& Dryden, 2015). The most fundamental therapeutic activity in CBT is the evaluation of these cognitions that are incompatible and not helpful to the client. After the client becomes able to identify ideas or images associated with negative emotions, she systematically examines the validity of her ideas, develops alternative perspectives, and tests them behaviorally (Wenzel, Brown, \& Beck, 2009, p.104).

The therapist tries to create cognitive change in the client by experimenting with every possible way to provide a lasting change in the client's feelings and behavior (Beck, 2001). However, the important point to be considered here is that clients come to psychotherapy not because they do not think rationally but because their feelings, behaviors, and social relations cause distress. For this reason, two basic points should not be omitted. First, thoughts and feelings are separate entities; and thoughts affect feelings and behavior. Second, therapists do not discuss feelings, but only discuss the thoughts that lead to these feelings (Leahy, 2008). Beck (2005) briefly outlined the goals of cognitive therapy as: (1) to know what they think, (2) to determine which ideas are distorted, (3) to search for arguments and evidence for questioning reality, (4) to bring forth possible alternatives to the wrong judgments, and (5) to receive feedback to inform oneself on whether the changes are correct or not. 
Although this cognitive model states that the mechanism underlying all psychological disorders is the client's dysfunctional thoughts that affect the mental state and behavior (Beck, 2001), Leahy (2004) emphasizes that experienced cognitive therapists should not approach each client with the same solution. According to him, the therapist should make a subjective conceptualization for each case, taking into account the cognitive schemes regarding the client's particular situation, coping styles, and social reality. As mentioned above, the client is applying for therapy because of deteriorations in his daily life. In this sense, it can be important to consider the social structure and spiritual beliefs that the client has. It should not be forgotten that some of the client's problems may be based on these spiritual beliefs, or that his spiritual life can support him in overcoming difficulties. Thus, religious beliefs can be central for the therapist in choosing the treatment of religious clients (Azhar, Varma, \& Dharop, 1994).

Some research shows that the use of spirituality in therapy can help religious clients. Barrera, Zeno, Bush, Barber, and Stanley (2012) state that spiritual beliefs and practices, together with a supportive environment, may improve coping with stressful life events and help depressed people find hope and meaning. But what should be noted here is that these beliefs should not make people feel guilty, though some cultures or religious beliefs can have high standards of behavior. The fear of making mistakes with regard to these high standards can cause a person's courage to break and bring on feelings of guilt. For this reason, it should be carefully examined whether spiritual factors increase or decrease depression. The therapist must determine whether the spiritual resources are an obligation or a source of "nutrition" for the client.

Spiritually oriented CBT follows the same process defined for secular CBT except that it uses religious beliefs and worship to encourage the client to change his or her mind and behavior (D'Souza \& Rodrigo, 2004; Koening, 2012; Tan \& Johnson, 2007). Standard CBT practice is performed at each session of a spiritually oriented CBT application, and prayer and sacred practices are integrated only when it is believed to be appropriate and helpful for the client. For example, the client may need to discuss feelings of guilt or punishment for their sins, the existence of religious suspicions, or the emotional and cognitive aspects of their beliefs. In this sense, in order to review the client's false or distorted thinking, all religious sources, such as sacred books and religious leaders, can be used as resources for therapy (Tan, 2007).

Tan (1996) proposes two models for the integration between spirituality and psychology: explicit (overt) and implicit (covert; as cited in Tan \& Johnson, 2007). In the implicit orientation, issues related to religion or spirituality are not discussed directly and are not systematically included in the process. Rather, their integration is 
covert and indirect. In the explicit orientation, issues related to religion or spirituality are handled more directly and systematically; and religious resources such as praying, reading sacred books and religious texts, religious experiences, going to places of worship, or joining in congregational worship can be used directly. The choice of which of these models to follow depends on the client's attitude and the therapist's knowledge and experience. For this reason, there are two questions that must be answered before using religious techniques in therapy. First, is religion an important source of conflict as part of the client's problems? For example, if feelings of guilt regarding a religious issue play an important role in the client's anxiety or depression, it may be useful for the therapist to dedicate time to help the client resolve these feelings. If the problem is a specific phobia, on the other hand, religious techniques are likely to be less helpful for the client (Vasegh, 2009).

The second and more important question is what is the significance of a religious/ spiritual technique for the client? For example, if a Muslim client has a negative attitude towards using religious scriptures or praying at counseling sessions, trying to use spiritually-oriented techniques during counseling can lead to resistance and negative emotions. In the same client, for example, techniques that can connect the client with God such as praying secretly and alone or reading the Qur'an can be more effective. In order to decide which methods to use in counseling, it would be helpful to hear the client's religious story and to gather information about the attitudes towards the use of these techniques in therapy in the first session (Vasegh, 2009). For this reason, in the first session of therapy, it is necessary to discuss these issues with the client before using techniques such as prayer and religious reading.

This interview in the first session should include the client's story, the problem list, and the list of goals that $\mathrm{s} / \mathrm{he}$ wants to accomplish, just as in the practice of secular CBT, along with spiritual issues such as the client's spiritual background, denominational status, and whether there are any drawbacks to using practices such as prayer and religious reading in therapy. Tan (2007) noted that the first interview in which all of this content is obtained could last about two hours. If the client responds positively and confirms that $\mathrm{s} / \mathrm{he}$ is informed (this can be done either verbally or in writing), then religiously/spiritually oriented CBT can be used.

\section{Examples of Spiritually Oriented CBT Practices}

CBT is a powerful approach in the treatment of religious clients who come with spiritual/religious problems because of its characteristics. The first of these features is the focus of CBT on the evaluation of people and the basis of their thinking. It is easy for highly religious and traditional clients to use a thought-oriented language and to share their assumptions about the combination of behavior and emotions. Second, CBT's emphasis on homework and learning does not seem foreign to many 
religious people who engage in religious activities (such as praying) and reading the sacred texts. Finally, religious people should be able to understand that they must work hard to achieve the change in attitudes and behaviors that CBT offers, given that, in the major traditional religions, stories and doctrines emphasize changes in thinking, attitudes, or behavior achieved through significant pain and suffering (Tan \& Johnson, 2007).

In fieldwork studies, it is seen that spiritually oriented CBT is not limited solely to individual sessions. For example, in Wong-McDonald's (2007) study, spiritually oriented CBT was applied to clients involved in psychosocial interventions with serious psychiatric difficulties, through such methods as praying, talking about God's forgiveness and love, and listening to religious music, while classical CBT was used for a control group. According to the results of the study, the clients who received spiritually oriented CBT attained therapy goals at significantly higher levels and had higher levels of well being during the three-year follow-up period. In another study, individual interviews were planned as modules (Barrera, Zeno, Bush, Barber, \& Stanley, 2012). Cognitive behavioral therapy was also applied in modules with twelve 40-minute sessions of therapy. In the first three sessions of this practice, the main components were informing about the structure and formation of anxiety through the use of awareness, motivational speaking, values assessment, deep breathing techniques, and relaxation techniques. In the following sessions, the client had the option to proceed with spiritually oriented psychotherapy. For the remaining eight sessions for these clients, modules with spiritually oriented techniques were selected with the therapist. Techniques such as behavioral activation, confrontation of anxiety, forgiveness of self and/or others, sleep regulation, problem-solving, deep muscle relaxation, and cognitive restructuring are applied by integrating spiritual practices in these selectable modules. Every week, telephone interviews are held to evaluate how the exercises and the homework are going. During the last CBT session, the skills are reassessed, and in the following weeks, the general progress of the counselor is assessed by telephone and follow-up interviews.

Good (2010) structured a religiously oriented CBT application for depression treatment consisting of 12 sessions. Spirituality and religious beliefs are integrated into the techniques of classical CBT for the treatment of depression, which include reward and activity planning, the discovery of the link between automatic thought and emotion and behavior, guided discovery and Socratic questioning, identifying cognitive distortions, relaxation, evidence analysis, and creating alternative thinking (Beck, 2005; Beck et al., 1979; DeRubeis et al., 2010). These spiritual techniques included Christianity-based meditation, using hymn chants, reciting a prayer that is prepared in line with the needs of the client and designated as homework at the end of each session, being present in depression, revising beliefs about God and spirituality, as well 
as the negative triad of self, others, and the future that typically exists in depression, talking about the positive effect of faith in treatment, determining spiritual coping strategies, working on the pain, and discovering barriers to forgiveness, using spiritual resources and stories to organize cognitive distortions, working on verses about God's forgiveness, discussing unconfessed sins, and using resources for spiritual purification.

\section{Techniques Used in Spiritually Oriented CBT}

When studies on spiritually oriented CBT are reviewed, it appears that the methods of classical CBT are the basis of therapy. Spiritually oriented techniques are integrated into these classical techniques, taking into account the needs and symptoms of the client. In the studies examined, the spiritual methods are generally as follows (D’Souza \& Rodrigo, 2004; Good, 2010; Rosmarin et al., 2011; Tan \& Johnson, 2007):

i. Discussing dysfunctional, disturbing and self-destructive thoughts through religious texts and recording thoughts and behaviors.

ii. Reading religious texts, praying or using religious images to reduce anxiety and to make the client feel better, either during counseling sessions or as a complement to cognitive homework assignments.

iii. Redefining cognitive beliefs through spiritual beliefs and trying to change the client's perspective with arguments such as "we are never alone; nothing is impossible; life is a test; we can only control the process, not the end; nothing is permanent."

iv. Helping clients to recognize their gratitude and to remember their blessings.

v. Following religious rituals such as praying and religious meditation with recordings or diary keeping and evaluating their effectiveness.

vi. Use of religious music.

In spiritually oriented CBT practice, reading religious books and praying for relief can help religious clients by reducing anxiety. Meditation can also be used as a successful technique in relieving clients. Praying is a different form of meditation. For this reason, it can be structured as a natural part of therapy (Azhar et al., 1994). A therapist may suggest ways for a client to calm himself and make himself feel safe before going to bed, such as praying, meditation, short spiritual readings, imagining, or listening to calming spiritual music if it is appropriate for the particular client (Barrera et al., 2012).

Spiritually oriented relaxation techniques. In deep muscle relaxation exercise, the therapist wants the client to focus on a spiritual image or word. During a relaxation 
exercise, the therapist can ask the client whether the spiritual things he imagines make him feel peaceful. The client then chooses the spiritual word or image that calms him down most effectively (Barrera et al., 2012). Wachholtz and Pargament (2008) found that, among the different forms of meditation, spiritually oriented meditation was more effective than other meditation techniques in reducing negative moods and anxiety levels, bringing about more intense spiritual emotions, and better coping with migraine attacks in patients with migraine problems. The meditation process also involves stopping negative thoughts and distracting attention from anxious thoughts. The clients can relax themselves by taking deep breaths while reading the holy books or focusing on their preferred spiritual word or image (Barrera et al., 2012).

Developing acceptance and gratitude skills. The therapist may suggest to the client that keeping certain spiritual thoughts in mind, such as "I am not alone," "A greater power will help me cope with my problems," "Only God can know what will happen in the future," can help him/her. The client may adopt these thoughts as suggested by the therapist or may create alternative ones for himself (Barrera et al., 2012). Spiritual resources can help a person who is buried in such processes as identification, relationships, and finding meaning in situations like cancer, where people get closer to death, which leads to the emergence of existential worries. In such cases, the methods to be applied should ensure that the client focuses on one of two aspects of control over life. The first is to focus on things that are under the control of the individual, and the second is to focus on things that are beyond control. Such an intervention would look like this: the therapist draws two circles on a paper, one representing "under my control" and the other representing "under God's control." Then the client is asked to write his concerns and problems in the appropriate two places. What the client writes is afterwards elaborated and discussed in the session. If the client has inappropriate placements, it is decided where the appropriate place is. As a final step, how the client can cope with the problems he places in the area controlled by God in alignment with his faith is discussed. This exercise can also be applied in groups (Rosmarin et al., 2011).

Rosmarin et al. (2011) developed a religiously oriented CBT application aimed to help the client become able to identify things to be grateful for and to think about things that are very valuable in the client's life, such as feelings, the health and ability of the physical body, or family members, especially children. Then the client is given a few seconds to think on these. After this time of thinking, the therapist says, "Imagine that what you value very much is not in your life, though it may not be very pleasant for you," and the client is given time to think again. Finally, the client is given the opportunity to consider what they have with fresh eyes as follows: "Now imagine that all this is a gift given to you and that all these gifts are made to make you feel happier and lead a better life." 
Again, in the same research, the clients were asked to think about a stressful event that they had experienced in the past that had turned out better than expected. The conclusions "Any event that is better than you expect is enough" and "It does not have to be a miracle" are given, and a few seconds are given to the client for thinking. Then the following question is formulated: "Try to imagine how you felt after this stressful event was resolved. Try to remember the stress you experienced. What did you expect about this situation that you were worried about?" Then the therapist asks, "Is there any opportunity to raise your belief in this case now? What did you endure in this stressful situation? How did you get out of this situation? I want you to think about these questions." The clients are allowed to share their experiences and are empowered to resort to these skills so that they can use them to manage similar stressful situations that they may encounter in the future. Researchers indicated that in each exercise the clients expressed greater levels of happiness, gratitude, and hope.

Clients are given suggestions of behaviors to include in their "spiritual daily lives," such as daily worship, reading religious books, or participating in religious activities. It may also be desirable to make a list that reminds the client of "what they are grateful for." The therapist may support the client in the creation of this list by asking, "If you prayed, would you pray for the kind of blessings that you already have in your life?" (Barrera et al., 2012).

Recognizing spiritual cognitive distortions. All religious people, from time to time, may have doubts and worries about things such as whether they have committed sin, performed a religious ritual correctly, or made genuine repentance. In general, people consider such thoughts and suspicions reasonably and are able to make logical decisions about whether there are things that need to be corrected. Some individuals, however, are subject to incorrect evaluations characterized by excessive doubt, which leads them to incorrect conclusions. Sometimes intense feelings of guilt can be associated with thoughts of being unbelievers or sinners. This situation increases their anxiety, making it difficult to engage in religious rituals, and can turn into religious obsession, such as trying to control thought, thought-action fusion, perfectionism, and intolerance of uncertainty. Often these people engage in a self-limiting struggle to control their unwanted thoughts of sin, punishment, and disrespect. As clients try to control these ideas more and more, they experience an increase in confused or uncontrolled thoughts (Vasegh, 2009). This struggle, which causes stress, is partly rooted in the belief that "bad thoughts are as immoral as bad behavior" (Purdon \& Clark, 2013). Yet Muhammad (pbuh) taught people that they would not be punished for their thoughts unless they cast their ideas into action. Sometimes religious obsessive thoughts can also be seen as a strong sign of faith (Vasegh, 2009). These beliefs can be debated by sharing this knowledge with the counselor and cognitive distortions can be revised. 
In the practice of spiritually oriented CBT, some special applications can be used for clients who have distorted religious thoughts. One of these is the use of religious books and religious evidence to test the validity of their self-destructive and irrational beliefs. In addition to this, interventions such as using religious images, praying in sessions, or religious readings to reduce the anxiety of the client are techniques that can be used as complements to cognitive homework assignments as well as during sessions. For example, if a client who struggles with low tolerance of frustration is disappointed that God does not respond to his prayer can be asked: "Do you have good evidence that God will not answer?" In this specialized form of discussion, the therapist can discuss the religious ideas and practices that are incompatible with the client's self-defined religion, unique to the client, or non-functional. For example, a therapist might share the verse "In the world you have tribulation, but take courage" [John 16:33] with a Christian client with low tolerance of frustration as contradictory evidence for her thoughts leading to lower frustration tolerance. Sometimes clients can misunderstand religious writings or read them in a biased manner by focusing on certain parts (Tan \& Johnson, 2007).

The cognitive therapist can also ask the client how the spiritual system of thought affects problem solving. For example, the therapist may ask the client how the greater power has a role in ones problem solving. The client may be asked, "Will you and the great power you believe in solve the problem together?" and the answers are discussed. In addition, when the therapist realizes that the client's cognitive distortions are due to lack of religious knowledge, he may suggest that it may sometimes be helpful to talk to religious leaders to solve certain problems or to find solutions by reading religious texts (Barrera et al., 2012).

Helping clients cope with losses. In general, clients with loss may feel sad when they have an intense desire for situations that cannot be reached, as evidenced by statements such as "if only my wife were still alive" or "It is terrible to be diabetic." Clients' belief in an afterlife in which they will have a better life may help them to better cope with these inimitable wishes or inevitable losses (Vasegh, 2009). Çünkü dua ederek Tanrı'ya başvurma, olayların sonuçlarını Tanrı'ya havale etme, sıkıntılar karşısında sabırlı olma, aileye yardım etme gibi davranışların ahirette ödüllendirileceğine inanmaktadır. Many people believe that acts such as praying to God, attributing the consequences of events to God, being patient with troubles, and helping others will be rewarded in the hereafter (Vasegh, 2009). The belief that patience in the face of troubles will be rewarded, or that all of life is a test, may increase their power to cope. For example, therapists can help disabled people partly improve their positive emotions and cope better with their situations by addressing spiritual power in their lives. Spiritual thoughts can be a source of support for both clients and those looking after them (Sue \& Sue, 2008). 
Coping with feelings of guilt and hopelessness. Criminality is as natural and sometimes beneficial as other negative feelings. For example, people with antisocial personality disorder feel guilt at lower levels, which are not strong enough to prevent them from inflicting violence on their victims. On the other hand, feeling very intense guilt is the most important cognitive component of depression. Feeling guilty can negatively affect the self-confidence in depressed clients thereby causing anxiety, unhappiness, disruptive behaviors, and fears of being punished in the future in this world of religious clients. Religious depressive clients may sometimes focus selectively on God's punishment and this can increase their feelings of guilt. These clients can be guided to direct their attention to hope-instilling verses and religious texts that emphasize that God is forgiving (Vasegh, 2009).

Some of the verses in the Qur'an can be discussed with Muslim clients to work on religious cognitive distortions. Verses such as the following can be discussed to support the client's awareness of religious cognitive distortions that cause them to feel despair:

"And if Allah should touch you with adversity, there is no remover of it except Him. And if He touches you with good - then He is over all things competent. (Qur'an 6:17')"

"There is not upon those who believe and do righteousness [any] blame concerning what they have eaten [in the past] if they [now] fear Allah and believe and do righteous deeds, and then fear Allah and believe, and then fear Allah and do good; and Allah loves the doers of good." (Qur'an 5:93)."

"And we will surely test you with something of fear and hunger and a loss of wealth and lives and fruits, but give good tidings to the patient, Who, when disaster strikes them, say, "Indeed we belong to Allah, and indeed to Him we will return. Those are the ones upon whom are blessings from their Lord and mercy. And it is those who are the [rightly] guided. (Qur'an 2: 155, 156, 157)"

Or the following verses can be elaborated on with a desperate client and the importance of patience without falling into despair can be discussed:

"And when We let the people taste mercy, they rejoice therein, but if evil afflicts them for what their hands have put forth, immediately they despair. Do they not see that Allah extends provision for whom He wills and restricts [it]? Indeed, in that are signs for a people who believe. (Qur'an 30: 36, 37)"

Some Muslim clients do not commit suicide because suicide is considered a grave sin. Promoting such ideas can be helpful in psychotherapy. One of the greatest sins mentioned in the Qur'an is the cessation of hope in the mercy of Allah. At this point,

1 In this paper, Qur'anic verses are taken from the translation known as the Saheeh International translation (2011, The Quran: English Meanings and Notes. Riyadh: AlMuntada) which is retrievable from https://quran.com/. 
it is important to note that some clients nevertheless consider suicide because they are very desperate, and the belief that hopelessness is a great sin can increase their despair and guilt even more (Vasegh, 2009).

The following verses can be discussed with the client to talk about God's forgiveness as well as how the client can forgive herself and overcome her sense of hopelessness:

\footnotetext{
"Whoever should think that Allah will not support [Prophet Muhammad] in this world and the Hereafter - let him extend a rope to the ceiling, then cut off [his breath], and let him see: will his effort remove that which enrages [him]? (Qur'an 22:15)"

"Then, indeed your Lord, to those who have done wrong out of ignorance and then repent after that and correct themselves - indeed, your Lord, thereafter, is Forgiving and Merciful. (Qur'an 16:119)"
}

The following verses can also be supportive while talking about the client's feelings of guilt and hopelessness:

\footnotetext{
"Who spend [in the cause of Allah] during ease and hardship and who restrain anger and who pardon the people - and Allah loves the doers of good. And those who, when they commit an immorality or wrong themselves [by transgression], remember Allah and seek forgiveness for their sins - and who can forgive sins except Allah? - and [who] do not persist in what they have done while they know. (Qur'an 3:134,135)"
}

As an example for spiritually oriented CBT interventions, Vasegh, utilized Socratic questioning technique with a female Muslim client in an effort to reduce feelings of guilt (2009). In this practice, the therapist emphasized the notion in the Qur'an that, even if one sins, if she repents and makes an effort to make up for the sin, she will be rewarded with great forgiveness of God. In this example, the client's feelings of guilt and despair were questioned through her experiences and combined with the knowledge of the Qur'an, enabling her to rethink her cognitive religious distortions.

\section{Spiritually Oriented CBT with the Elderly}

Especially towards the last stages of life, older clients can apply therapy to address problems regarding reassessment of life, death, and hopelessness. There are some points to be aware of when practicing spiritually oriented CBT with older religious clients, and especially with religious counselors who have cognitive and physiological difficulties due to their age.

Several interventions have been proposed in the literature on this specific group of clients who have cognitive and physiological difficulties due to their age. Snodgrass (2009) applies the following steps in her spiritually oriented CBT approach to older individuals: 
Snodgrass (2009) applies the following steps in the spiritually oriented CBT approach on elderly people. At the first meeting, the client's story is conceptualized within the CBT framework and terminology with reference to the client's age, demographic characteristics, family structure, how s/he expresses his/her problem, and personal history. At the same time, life constraints due to diseases caused by old age can also cause depression. For this reason, it is important to identify these diseases. At the initial assessment, the client's spiritual orientation and thoughts are understood. Similarly, Tan (2007) notes that, in the practice of spiritually oriented CBT, information about the spiritual beliefs and practices of clients should be obtained within the first two sessions. In the second interview, the deeper spiritual views of the client are better assessed. For this, the therapist examines the client's spiritual past and attempts to determine the role, if any, that his past spiritual beliefs play in his/her current life. Thus it is possible to determine which applications to use in order to get started and add meaning to the client's life.

Even if an elderly client is not aware of going through a therapeutic process, it is very important for the therapist to give the client information about the goals and process of CBT. In this explanation, a simple and understandable language is used. The therapist makes further explanations about homework assignments and goals, but is mindful of making it a dialogue rather than a lecture. Initially, the therapist can discuss the content of the spiritual dimension with the client. For example, the therapist can ask the client whether he or she would benefit from meditation or prayer at the beginning or end of the counseling session. In addition, the therapist, as one of the figures at the center of CBT, trains counselors on spiritual cooperation. In cognitive restructuring, firstly, elderly clients are trained about myths about old age. Hope is encouraged as the most important approach to cognitive restructuring. If there are cognitive distortions in their beliefs, these are also worked on.

\section{Ethical Responsibility in Spiritually Oriented CBT Practice}

Spiritually orientated CBT therapists support their clients in using their own religious doctrines and behaviors to transform the thinking, values, and behaviors that disrupt their harmony into a more meaningful, hopeful, optimistic worldview. In all respects, therapists must respect the spiritual realm of the client (D'Souza \& Rodrigo, 2004; Koening, 2012). Post and Wade (2009) examined daily practices and literature and identified the difficulties and important points that could arise in spiritually oriented therapies. These points were:

i. When psychotherapists are compared to the clients they serve, they tend to emphasize religion less and spirituality more. For this reason, it is very important for therapists who practice spiritually oriented counseling to receive supervision, not only to recognize the client's potential for spirituality but also to ensure that they feel comfortable working 
clinically about these issues (Polonski, 2003). In supervision exercises, the effect of the counselor's family background on his/her spiritual orientation can be investigated with the genogram technique. For therapists, becoming aware of their own thoughts and prejudices regarding spirituality is an important goal (Bartoli, 2007).

ii. Therapists generally state that they have never received any education or have very little knowledge in spiritual matters. This causes therapists not to trust themselves in spiritual counseling.

iii. Many spiritual or religious clients may want to talk about spiritual issues in therapy. In this regard, the therapist can routinely assess the treatment preferences of his clients with respect.

iv. Some clients want their therapists to use spiritual interventions in therapy. For many spiritually oriented clients, both religious and non-religious therapists can effectively apply these techniques.

v. Spiritual issues can sometimes be associated with problems in therapy. For this reason, the therapist can regularly evaluate the client's spiritual history and concerns.

vi. Spiritual clients often find it very helpful to talk about spiritual issues. Talking over these issues may save time when the client starts to build a therapeutic relationship with the therapist, for example during the first session, and the acceptance of the client's spiritual worldview by the therapist may also improve trust.

vii. Experimental evidence indicates that spiritual interventions are often effective. (Azhar et al., 1994; Azhar \& Varma, 1995; Razali et al., 2002). For this reason, it is good for therapists to consider using spiritual techniques when appropriate.

A CBT therapist must have a good education and sufficient experience in this field. In spiritually oriented CBT practice, the therapist may need to explain the cognitive distortions that the client has, taking into account his/her religious and spiritual considerations. In this case, the therapist's own religious and spiritual views can influence the spiritually oriented CBT process (Tan \& Johnson, 2007). While therapists have knowledge of their own spiritual beliefs, they may not have knowledge of the spiritual belief systems of clients with different beliefs. If the therapist is not careful, this may cause him/her to behave in a biased manner (Plante, 2007). There are two situations that a CBT therapist should attend to ethically, especially when working with a religious client (Tan \& Johnson, 2007). Therapists should not marginalize or reject the client's religious beliefs no matter how unconventional or controversial they seem, and they should not try to dispute or disprove the principal religious ideas of the client, whether implicitly or explicitly.

Another more specific requirement is that the therapist has sufficient knowledge on and experience with the religious view that the client is involved in. It will thus be possible to discuss with the client the particular considerations that are not in accordance with the mainstream views of the religion that the client is involved in and that are not functional. Sometimes the client and the therapist can work together to correct beliefs that are not in line with the true nature of the religious texts (Tan \& Johnson, 2007). 
According to Elkonin, Brown, and Naicker's study (2012), it is not easy for therapists to vocalize the concepts of religion and spirituality, and a considerable deal of literature needs to be read on the subject in order to achieve confidence in discussing them. In addition, it is difficult for therapists to reach a consensus on certain topics regarding religion and spirituality. In the same study, it was also found that some of the participants had a more negative evaluation of spirituality while others had more positive meanings associated with spirituality. A large number of therapists have indicated that spirituality can be used therapeutically in the direction of the client's needs and guidance. In the qualitative study conducted by Ekşi, Takmaz, and Kardaş (2016) in Turkey, psychological counselors gave importance to spirituality in the counseling process, and stated reasons for the inclusion of spirituality in the therapeutic process. Developing standards for application and supervision is important for spiritually oriented psychotherapy in general, as well as spiritually oriented CBT specifically.

\section{Conclusion}

It is not possible for spirituality, which occupies an important place in the lives of many individuals and determines their social relations, to be excluded from the framework of a science that carries the purpose of understanding human beings such as psychology and the practice of psychotherapy. The literature reveals that it is necessary for therapists who practice spiritually oriented CBT to have good knowledge, experience, and skills in the field of CBT, as well as a strong knowledge of the religious beliefs of the clients whom they serve. Otherwise, many ethical problems may arise in practice. In this sense, the therapist should have acquired relevant training and experience and the process should be followed up with supervision to support the practice of spiritually oriented CBT.

The guidance of spirituality, which has historically played an important role in human existence, should also be considered in therapy sessions, along with other multiple thought systems that affect the surrounding social structures. Human beings and human behavior were conceptualized as non-interactive parts for many years, mostly due to an excessive trust in science and a reductionist attitude in the treatment offered to clients. This attitude contributes to the failure to take a holistic view of life and to understand our spiritual formation (Sue \& Sue, 2008). Yet, in many areas of science, and in particular with paradigm shifts in psychology, there has been a change in our understanding of the nature of reality. Scientists and practitioners are beginning to work on phenomena related to unobservable aspects of the human creature such as spirituality. Subjective evaluations by researchers are not undesirable; rather, they play a role in influencing the process of acquiring information. With this transformation, there has been an increase in research on spirituality in psychology, 
and the results of these studies are also reflected in therapy applications. It should be noted that there have always been efforts to address this important area of human experience in psychology dating back to the early prominent psychologists such as William James; yet, recent paradigm shifts have accelerated the acceptance of spirituality as a relevant area of study and psychological resource.

In several studies, the therapeutic acceleration effect of spiritually oriented CBT with religious counselors has been documented. At the same time, however, these practices have created some new problems and areas of need. For example, Rosmarin et al. (2011) state that spiritual thoughts shape how people perceive themselves, the world and the future, and that spiritual integration of cognitive models is important, but they add that it may create uncertainty when applied without forming a theoretical model that avoids oversimplification and that has been authenticated through testing its suitability with spirituality.

Spiritually oriented psychotherapy is already used in clinical practice, but it is still at the beginning of its history and there are many issues to be investigated (Wolf \& Stevens, 2001). While a considerable accumulation has begun to emerge in the worldwide literature in this area, it can be said that the practice of spiritually oriented therapy for Turkey is "in the midst of a stir yet." Most of the available Turkish studies on spirituality are correlational or scale adaptation/development studies (Ayten \& Anık, 2014; Ayten, Anık, \& Eryücel, 2013; Ayten, Göçen, Sevinç, \& Öztürk, 2012; Ayten \& Sağır, 2014; Coşkunsever, 2016; Göcen, 2013; Karakuş \& Koç, 2014; Kula, 2002; Şentepe, 2013), whereas therapeutic and group counseling examples of spiritually oriented CBT applications are very few (Kamakcan \& Şirin, 2013). It is clear that the studies being conducted are screening studies on the use of religious coping methods in general.

In this sense, the development of suitable therapeutic applications of spiritually oriented CBT for Turkey and countries with similar religious and cultural characteristics, as well as experimental trials on these applications, is important. Spiritually oriented CBT can be implemented with many spiritual and religious clients in these countries and positive results can be obtained in these applications. However, the existence of different sects must be considered when these studies are conducted. Therapists need to have in-depth knowledge of belief systems and religious practices of different religious denominations. In these countries, there remains a great need for psychological units that provide such training. In addition, compliance with ethical rules is not audited in practice. The lack of adequate training for spiritually oriented therapies and the lack of control with respect to ethical practices create the risk of impairing functioning by exposing the use of spirituality in these countries. 


\section{References}

Ayten, A., \& Sağır, Z. (2014). Dindarlık, dinî başa çıkma ve depresyon ilişkisi: Suriyeli sığınmacılar üzerine bir araştırma [The relations between religiosity, religious coping and depression: A study on Syrian refugees]. Marmara Üniversitesi İlâhiyat Fakültesi Dergisi, 47, 5-18. http://dx.doi. org/10.15370/muifd.86222

Ayten, A., \& Anık, E. (2014). LGBT bireylerde dinî inanç, din ve tanrı tasavvuru, dinî ve manevî başa çıkma süreci [Religious belief, representations of religion and god, and reli-gious/spiritual coping process among lesbian, gay, bisexual and transsexual individuals]. Dinbilimleri Akademik Araştırma Dergisi, 14(2), 7-31.

Ayten, A., Göcen, G., Sevinç, K., \& Öztürk, E. (2012). Dini başa çıkma, şükür ve hayat memnuniyeti ilişkisi: Hastalar, hasta yakınları ve hastane çalışanları üzerine bir araştırma [The relations of religious coping, gratitude and life satisfation: A case study on patients, patient relatives and hospital staff]. Dinbilimleri Akademik Araştırma Dergisi, 12(2), 45-79.

Azhar, M. Z., \& Varma, S. L. (1995). Religious psychotherapy as management of bereavement. Acta Psychiatr Scandinavica, 91, 233-235.

Azhar, M. Z., Varma, S. L., \& Dhorap, A. S. (1994). Religious psychotherapy in anxiety disorder patients. Acta Psychiatrica Scandinavica, 90, 1-3.

Barrera, T. L., Zeno, D., Bush, A. L., Barber, C. R., Stanley, M. A. (2012). Integrating religion and spirituality into treatment for late-life anxiety: Three case studies. Cognitive and Behavioral Practice, 19, 346-358.

Bartoli, E. (2007). Religious and spiritual issues in psychotherapy practice: Training the trainer. Psychotherapy: Theory, Research, Practice, Training, 44(1), 54-65. http://dx.doi. org/10.1037/0033-3204.44.1.54

Beck, A. T. (2010). Cognitive models of depression In R. L. Leahy \& E. T. Dowd (Eds.), Clinical advances in cognitive psychotherapy theory and application (pp. 29-61). New York, NY: Springer Publishing Company.

Beck, A. T. (2005). Bilişsel terapi ve duygusal bozukluklar [Cognitive therapy and emotional disorders] (T. Özakkaş, Trans.). Istanbul, Turkey: Litera Yayıncılık.

Beck, A. T., Rush, J. A., Shaw, B. F., \& Emery, G. (1979). Cognitive therapy of depression. New York, NY: The Guilford Press.

Braam, A. W., Klinkenberg, M., Galenkamp, H., \& Deeg, D. J. H. (2012). Late-life depressive symptoms, religiousness, and mood in the lastweek of life. Depression Research and Treatment. http://dx.doi.org/10.1155/2012/962860

Cole, B., \& Pargament, K. I. (1999). Re-creating your life: A spiritual: Psychotherapeutic intervention for people diagnosed with cancer. Psycho-Oncology, 8, 395-407.

Corey, G. (2008). Psikolojik danışma, psikoterapi kuram ve uygulamaları [Theory and practice of counseling and psychotherapy] (T. Ergene, Trans.). Ankara, Turkey: Mentis Yayıncılik.

Corey, G. (2013). Case approach to counselig and psychotherapy. Belmont, CA: Brooks/Cole Cengage Learning.

Coşkunsever, A. (2016). Yetiştirme yurdunda kalan ergenlerin yaşadıkları sorunlar ve dini başa çıkma: Bursa ve Şanlıurfa yetiştirme yurtları örneği [Problems of adolescents in orphanages and religious coping: Example of Bursa and Şanlıurfa orphanages]. Uludă Üniversitesi Ilahiyat Fakültesi Dergisi, 25(2), 97-124. 
D’Souza, R., \& Rodrigo, A. (2004). Spiritually augmented cognitive behavioural therapy. Australasian Psychiatry, 12(2), 148-152.

DeRubeis, R. J., Webb, C. A., Tang, T. Z., \& Beck, A. T. (2010). Cognitive therapy. In K. S. Dobson (Eds.), Handbook of cognitive-behavioral therapies (pp. 277-316). New York, NY: The Guilford Press.

Ekşi, H., Takmaz, Z., \& Kardaş, S. (2016). Spirituality in psychotherapy settings: A phenomenological inquiry into the experiences of Turkish health professionals. Spiritual Psychology and Counseling, 1(1), 89-108. http://dx.doi.org/10.12738/spc.2016.1.0005

Elkonin, D., Brown, O., \& Naicker, S. (2012). Religion, spiritually and therapy: Implications for training. Springer Science+Business. Advance online publication. http://dx.doi.org/10. 1007/ s10943-012-9607-8

Eryücel, S. (2013). Yaşam olayları ve olumlu dini başa çıkma [Life events and positive religious coping]. Mustafa Kemal Üniversitesi Sosyal Bilimler Enstitüsü Dergisi, 10(23), 251-271.

Göcen, G. (2013). Pozitif psikoloji düzleminde psikolojik iyi olma ve dini yönelim ilişkisi: Yetişkinler üzerine bir araştırma [Pyschological well-being and religious orientation in terms of positive psychology: A research about adults]. Toplum Bilimleri Dergisi, 7(13), 97-130.

Good, J. J. (2010). Integration of spirituality and cognitive-behavioral therapy for the treatment of depression (Doctoral dissertation, Philadelphia College of Osteopathic Medicine Department of Psychology). Retrieved from http://digitalcommons.pcom.edu/cgi/viewcontent.cgi?article=105 4\&context=psychology_dissertations

Harman, Ö. F. (1994). Din [Religion]. In TDV İslam ansiklopedisi (Vol. 9). Istanbul, Turkey: Türkiye Diyanet Vakfı Yayınları.

Hill, P. C., Pargament, K. I., Hood, R. W., McCullough Jr, M. E., Swyers, J. P., Larson, D. B., \& Zinnbauer, B. J. (2000). Conceptualizing religion and spirituality: Points of commonality, points of departure. Journal for the Theory of Social Behaviour, 30(1), 51-77.

Karakuş, A. C., \& Koç, M. (2014). Stresle başa çıkma ve dini başa çıkma yöntemleri arasındaki ilişkinin çeşitli değişkenler açısından incelenmesi [The relationship between religious coping and coping with stress methods: An analysis from various of variable]. Insan ve Toplum Bilimleri Araştırmaları Dergisi, 3(3), 569-590.

Kaymakcan, R., \& Şirin, T. (2013). Bilişsel-davranışçı psikoterapi yaklaşımı ile bütünleştirilmiş dini danışmanlık modeli'nin din eğitimi alan erkek üniversite öğrencilerinin durumluk ve sürekli kayg1 düzeylerine etkisi [The effect of the Islamic counseling model combined with cognitive-behavioral psychotherapy on the state and trait anxiety levels of male university students receiving religious education]. Journal of Values Education, 11(26), 111-148.

Koening, H. G. (2012). Religious versus conventional psychotherapy for major depression in patients with chronicmedical illness: Rationale, methods, and preliminary results. Hindawi Publishing Corporation Depression Research and Treatment, Online publication. http://dx.doi. org/10.1155/2012/460419

Leahy, R. L. (2008). Bilişsel terapi yöntemleri [Cognitive therapy and methods] (H. Türkçapar \& E. Köroğlu, Trans.). Ankara, Turkey: Hekimler Yayın Birliği.

Leahy, R. L. (2004). Bilişsel terapi ve uygulamalar [Practicing cognitive therapy: A guide to intervention] (H. Hacak, M. Macit \& F. Özpilavc1, Trans.). Istanbul, Turkey: Litera Publishing.

Neenan, M., \& Dryden, W. (2015). Cognitive behavioral therapy 100 key points \& techniques. New York, NY: Routledge. 
Paloutzian, R. F., \& Park, C. L. (2005). Integrative themes in the current science of the psychology of religion. In R. F. Paloutzian \& C. L. Park (Eds.) Handbook of the psychology of religion and spiritually (pp. 3-20). New York, NY: The Guilford Press.

Pargament, K. I., \& Saunders, S. M. (2007). Introduction to the special issue on spirituality and psychotherapy. Journal of Clinical Psychology, 63(10), 903-907. http://dx.doi.org/10.1002/ jclp.20405

Pargament, K. I. (2007). Spiritually integrated psychotherapy understanding an adressing the sacred. New York, NY: The Gullford Press.

Pargament, K. I., Zinnbauer, B. J., Scott, A. B., Butter, E. M., Zerowin, J., \& Stanik, P. (1998). Red flags and religious coping: Identifying some religious warning signs among people in crisis. Journal of Clinical Psychology, 54(1), 77-89.

Plante, T. G. (2007). Integrating spirituality and psychotherapy: Ethical issues and principles to consider. Journal of Clinical Psychology, 63(9), 891-902.

Polanski, P. J. (2003). Spirituality in supervision. Counseling and Values, 47, 131-141.

Post, B. C., \& Wade, N. G. (2009). Religion and spirituality in psychotherapy: A practice-friendly review of research. Journal of Clinical Psychology, 65(2), 131-146.

Purdon, C., \& Clark, D. A. (2013). Takıntılarla başa çıkma [Overcoming obsessive thoughts] (I. Gündoğdu, Trans.). Istanbul, Turkey: Psikonet Yayınları.

Razali, S. M., Aminah, K., \& Khan, U. A. (2002). Religious-cultural psychotherapy in the management of anxiety patients. Transcultural Psychiatry, 39(1), 130-136.

Rosmarin, D. H., Auerbach, R. P., Bigda-Peyton, J. S., Björgvinsson, T., \& Levendusky, P. E. (2011). Integrating spirituality into cognitive behavioral therapy in an acute psychiatric setting: A pilot study. Journal of Cognitive Psychotherapy: An International Quarterly, 25(4), 287-303.

Rosmarin, D. H., Pirutinsky, S., Auerbach, R. P., Björgvinsson, T., Bigda-Peyton, J., Andersson, G., ... Krumrei, E. J. (2011). Incorporating spiritual beliefs into a cognitive model of worry. Journal of Clinical Psychology, 67(7), 691-700. http://dx.doi.org/10.1002/jclp.20798

Şentepe, A. (2013). Yaşl11ık döneminde dini başaçıkma [Religious coping in old age period]. İnsan ve Toplum Bilimleri Araştırmaları Dergisi, 4(1), 186-205. http://dx.doi.org/10.15869/ itobiad.03791

Snodgrass, J. (2009). Toward holistic care: Integrating spirituality and cognitive behavioral therapy for older adults. Journal of Religion, Spirituality \& Aging, 21, 219-236. http://dx.doi. org/10.1080/15528030902803913

Sperry, L., \& Shafranske, E. P. (2007). Spiritually oriented psychotherapy. Washington, DC: American Psychological Association.

Sue, W. D., \& Sue, D. (2008). Counseling the culturally diverse theory and practise. New Jersey, NJ: John Wiley \& Sons, Inc.

Tan, S.-Y., \& Johnson, W. B. (2007). Spiritually oriented cognitive-behavioral therapy. In, L Sperry \& E. P. Shafranske (Eds.), Spiritually oriented psychotherapy (pp. 77-103). Washington, DC: American Psychological Association.

Tan, S.-Y. (2007). Use of prayer and scripture in cognitive-behavioral therapy. Journal of Psychology and Christianity, 26(2), 101-111.

Vasegh, S. (2009). Psychiatric treatments involving religion: Psychotherapy from an Islamic perspective. P. Huguelet \& H. G. Koening (Eds.), Religion and Spirituality in Psychiatry (pp. 301-316). Cambridge, UK: Cambridge University Press. 
Wachholtz, A. B., \& Pargament, K. I. (2008). Migraines and meditation: Does spirituality matter? Journal of Behavioral Medicine, 31, 351-366. http://dx.doi.org/10.1007/s10865-008-9159-2

Weber, L. J., \& Cummings, A. L. (2003). Relationships among spirituality, social support, and childhood maltreatment in university students. Counseling and Values, 47, 82-95.

Wenzel, A., Brown, G. K., \& Back, A. T. (2009). Cognitive therapy for suicidal patients: Scientific and clinical application (pp. 104-125.). Washington, DC: American Psychological Association.

Wolf, C. T., \& Stevens, P. (2001). Integrating religion and spirituality in marriage and family counseling. Counseling and Values, 46, 66-75.

Wong-McDonald, A. (2007). Spirituality and psychosocial rehabilitation: Empowering persons with serious psychiatric disabilities at an inner-city community program. Psychiatric Rehabilitation Journal, 30, 295-300. http://dx.doi.org/10.2975/30.4.2007.295.300

Worthington, E. L., \& Aten, J. D. (2009). Psychotherapy with religious and spiritual clients: An introduction. Journal of Clinical Psychology, 65(2), 123-130. 
